\title{
Uniting Public Health and Primary Care for Healthy Communities in the COVID-19 Era and Beyond
}

\author{
John M. Westfall, MD, MPH, Winston Liaw, MD, Kim Griswold, MD, Kurt Stange, MD, \\ Larry A. Green, MD, Robert Phillips, MD, Andrew Bazemore, MD, \\ Carlos Roberto Jaén, MD, Lauren S. Hughes, MD, Jen DeVoe, MD, Heidi Gullett, MD, \\ James C. Puffer, MD, and Robin S. Gotler, $M A$
}

The Coronavirus disease 2019 (COVID-19) pandemic has laid bare the dis-integrated health care system in the United States. Decades of inattention and dwindling support for public health, coupled with declining access to primary care medical services have left many vulnerable communities without adequate COVID-19 response and recovery capacity. "Health is a Community Affair" is a 1966 effort to build and deploy local communities of solution that align public health, primary care, and community organizations to identify health care problem sheds, and activate local asset sheds. After decades of independent effort, the COVID-19 pandemic offers an opportunity to reunite and align the shared goals of public health and primary care. Imagine how different things might look if we had widely implemented the recommendations from the 1966 report? The ideas and concepts laid out in "Health is a Community Affair" still offer a COVID-19 response and recovery approach. By bringing public health and primary care together in community now, a future that includes a shared vision and combined effort may emerge. ( J Am Board Fam Med 2021;34:S203-S209.)

Keywords: Community Medicine, CovID-19, Integrated Health Care Systems, Pandemics, Primary Health Care, Public Health

\section{America's Health in a Dis-Integrated Health System}

The Coronavirus disease 2019 (COVID-19) pandemic lays bare the profound inadequacy of the US health system for addressing the country's acute health needs, our chronic disease crisis, and the root causes of health inequities, for example, structural racism and classism. ${ }^{1-8}$

For decades, we have failed to invest in 2 of the cornerstones of our communities' health and wellness:

This article was externally peer reviewed.

Submitted 31 August 2020; revised 16 October 2020; accepted 19 October 2020.

From the Robert Graham Center for Policy Studies in Primary Care, American Academy of Family Physicians, Washington, DC (JMW); Health Systems and Population Health Sciences, University of Houston, College of Medicine, TX (WL); Department of Family Medicine, Jacobs School of Medicine and Biomedical Sciences, State University of New York at Buffalo (KG); Departments of Family Medicine and Community Health, Population and Quantitative Health Sciences, General Medical Sciences and Sociology, and Case Comprehensive Cancer Center Case, Western Reserve University Cleveland, OH (KS); Farley Health Policy Center, University of Colorado School of Medicine Aurora, CO (LAG, LSH); Center for Professionalism and Value in Health Care, American Board of Family Medicine, Washington, DC primary care and public health, and their integration into a single system of community care. ${ }^{9-11}$ Primary care, where millions of Americans go for comprehensive, continuous, preventive, and personal health care, has been relegated to 1 of the dozens of "service lines" in a giant profitable health care industrial complex, undermining the healing effects of the relationship between patients, personal physicians and care providers, and their teams. ${ }^{12-14}$ Meanwhile, public health, which focuses on population health, disease prevention, upstream drivers of inequity, wellness,

(RP, AB); Departments of Family \& Community Medicine and Population Health Sciences Lozano Long School of Medicine, University of Texas Health, San Antonio (CRJ); Larry A. Green Center for the Advancement of Primary Health Care for the Public Good, Virginia Commonwealth University, Richmond (KS, RSG); Cuyahoga County Board of Health, Parma, OH (HG); Department of Family Medicine, Oregon Health and Science University, Portland (JD); American Board of Family Medicine (JCP); Center for Community Health Integration, Case Western Reserve

University, Cleveland, OH (KS, RSG).

Funding: None.

Conflict of interest: None.

Corresponding author: Jack M. Westfall, MD, The Robert Graham Center, 1133 Connecticut Ave NW, Suite 1100,

Washington, DC 20026 (E-mail: jwestfall@aafp.org). 
behavioral health, and emergency preparedness, is chronically underfunded. ${ }^{15-17}$ Health care is not alone as shown by its ineffective response to COVID-19 and our underlying social structure. Other factors impacting health such as public education, law enforcement, social services, environment, and climate change are also suffering from inadequate attention and resources.

Primary care and public health share vital common ground and synergistic goals. ${ }^{18}$ There is overwhelming evidence that their life-saving, costeffective efforts prevent disease and injury, improve community conditions and quality of life for those with chronic conditions, and provide crucial disaster preparedness. ${ }^{17}$ They are natural partners and leaders in robust and lasting population health efforts. This article presents a vision of a comprehensive, collaborative system of community care that simultaneously responds to the challenges exposed by COVID-19 and positions the United States to address future epidemics while producing health, containing costs, and relieving inequities.

\section{An Integrated Approach}

A powerful proposal for a health care system that engages primary care leadership within a broad community-public health framework was developed in the 1966 report, "Health is a Community Affair," ${ }^{19}$ and updated in $2012 .{ }^{20}$ The report (often referred to as the Folsom Report for its chair Marion Folsom) was the result of a 3-year study of healthy communities framed on the notion of "communities of solution," an approach to health care issues defined by problems to be solved rather than geographic locales, specific delivery systems, or governmental agencies. A community of solution is comprised of people who come together to address an important problem or seize an opportunity to improve health. In addition to community members, primary care clinicians, and public health professionals, communities of solution include an array of public and private partners and community-based organizations depending on the nature of the problem and the community.

While amazingly prescient, the 1966 report's visionary recommendations were only temporarily embraced and not widely implemented. Now, however, "Health is a Community Affair" has new relevance as we work to solve the seemingly intractable problems that confront the American health care system. It offers a roadmap for local planning, organization, and delivery of health services without the barriers of complex political and administrative structures. Within its framework, primary care is united with public health and behavioral health (a core component of primary care services) in education, practice, and policy. Together, these sectors create and work in partnerships, assist in data sharing with community organizations, and achieve the highest level of coordinated community care. It is a flexible framework that can, for example, incorporate community health workers into the health care team to support its broader community-engaged approach and address the interface of social, public health, and medical care needs within specific communities. The goal of a Community of Solution is to identify the problem shed - that region, population, group of people with a common experience, suffering from a health problem - and then engage and activate the local asset shed - the primary care, public health, community organizations available to address the problem. In addition, local communities must have access to state and national assets as well. This requires a thoughtful plan that provides flexibility and innovation in how local communities may access state and national resources.

"Health is a Community Affair" is also the basis for new approaches to resource allocation. ${ }^{21} \mathrm{~A}$ comprehensive, multidisciplinary approach to care requires payment models that incorporate primary care, behavioral health, and public health in a shared funding bucket. On a local level, a community of solution that can address problems within context will require local assets drawn from public health, primary care, and the broader community. Such partnerships grounded in local context and built on trusting relationships enable systems-level interventions along with programmatic work to tackle multifaceted causes of health inequities that are impossible to remedy in 1 isolated sector. ${ }^{22}$ Implementing such partnerships requires funding and development of new enabling infrastructure as well as engagement of a wide variety of people, agencies, and practices, rather than single organizational entities. ${ }^{23}$

\section{COVID-19 Response and Recovery}

The COVID-19 pandemic demands a comprehensive community asset engagement effort and highlights the need to work across boundaries. ${ }^{24-26}$ The community of solution roadmap in "Health is a 


\begin{tabular}{|c|c|c|}
\hline & Needs & $\begin{array}{l}\text { How Public Health and Primary Care Can } \\
\text { Collaborate }\end{array}$ \\
\hline \multirow[t]{2}{*}{$\begin{array}{l}\text { Testing, tracking, and } \\
\text { tracing }\end{array}$} & $\begin{array}{l}\text { Isolate cases and quarantine contacts to } \\
\text { reduce transmission }\end{array}$ & $\begin{array}{l}\text { Expand and link public health and primary } \\
\text { care testing } \\
\text { Provide patient identification, supportive } \\
\text { treatment, and resource support for } \\
\text { isolation } \\
\text { Establish contact identification and tracing } \\
\text { and provide resource support for } \\
\text { quarantine }\end{array}$ \\
\hline & $\begin{array}{l}\text { Identify patients who have had COVID-19 } \\
\text { infections }\end{array}$ & $\begin{array}{l}\text { Develop protocols for interpreting and } \\
\text { implementing serologic testing } \\
\text { Conduct multi-system analyses on the impact } \\
\text { of COVID-19 infection on functional, } \\
\text { behavioral, and financial impairment }\end{array}$ \\
\hline $\begin{array}{l}\text { Identify, investigate, and } \\
\text { manage clusters }\end{array}$ & $\begin{array}{l}\text { Using electronic health and public health } \\
\text { records, identify the locations and } \\
\text { mechanisms of infection } \\
\text { transmissionIdentify equity-grounded } \\
\text { strategies to address clusters }\end{array}$ & \\
\hline Recovery & Plan for mass immunization & $\begin{array}{l}\text { Stratify risk to inform vaccine distribution } \\
\text { Deliver vaccine education by leveraging } \\
\text { community partnerships } \\
\text { Distribute vaccines } \\
\text { Identify immunization locations (eg, public } \\
\text { health departments, points of dispensing, } \\
\text { pharmacies, schools, community centers/ } \\
\text { YMCAs, and community health centers, } \\
\text { long-term care facilities, shelters) }\end{array}$ \\
\hline \multirow{2}{*}{$\begin{array}{l}\text { Community } \\
\text { identification, } \\
\text { creation, and } \\
\text { engagement.Engaging } \\
\text { patients to address } \\
\text { ongoing needs }\end{array}$} & $\begin{array}{l}\text { Identify patients in need of primary care (ie, } \\
\text { continuous, comprehensive, coordinated, } \\
\text { and first contact care) }\end{array}$ & $\begin{array}{l}\text { Provide diagnosis, treatment, and careIn- } \\
\text { personTelehealthMobile delivery to homes }\end{array}$ \\
\hline & $\begin{array}{l}\text { Identify patients with (or at risk of) mental, } \\
\text { emotional, or behavioral health problems }\end{array}$ & $\begin{array}{l}\text { Provide treatment and referrals } \\
\text { Deliver suicide prevention interventions } \\
\text { Address substance use } \\
\text { Target: } \\
\text { Youth and young adults } \\
\text { Elderly } \\
\text { Other at-risk communities including } \\
\text { homeless, non-English speakers, refugees, } \\
\text { migrant workers, individuals with serious } \\
\text { mental illnesses }\end{array}$ \\
\hline Integrate care & $\begin{array}{l}\text { Integrate across multiple domains, including } \\
\text { prevention, acute illness, chronic disease } \\
\text { management, multiple chronic conditions, } \\
\text { mental health, and family care, long-term } \\
\text { care, assisted living. }\end{array}$ & \\
\hline $\begin{array}{l}\text { Community leadership } \\
\text { development }\end{array}$ & $\begin{array}{l}\text { Create local community medical, public } \\
\text { health leadership activities }\end{array}$ & $\begin{array}{l}\text { Provide opportunities for clinicians } \\
\text { (Physicians, NPs, PAs) to meet regularly } \\
\text { with public health leadership } \\
\text { Co-create education and community } \\
\text { programs that would feature primary care } \\
\text { and public health teams } \\
\text { Partner with medical and other health } \\
\text { professions educational institutions to } \\
\text { educate and train the future health } \\
\text { workforce }\end{array}$ \\
\hline
\end{tabular}

Abbreviations: NP, nurse practitioner; PA, physician assistant; COVID-19, Coronavirus disease 2019.

Community Affair" is the pole star for such efforts (Table 1). A community-based COVID-19 mitigation plan can be implemented in real-time building on prior investment in trusting and trustworthy relationships and involving public health professionals, primary care clinicians, behavioral health professionals, allied health partners, community members, and institutional leadership. Communities 
of solution are already forming in response to the pandemic as towns, regions, and states span boundaries of geography and discipline to share resources, provide emotional support, and plan for the future, ${ }^{27}$ with community members emerging as essential colleagues in the process. Other emerging ideas, such as a rapidly scalable workforce for contact tracing, a Community Health Worker Corps, and a WPAstyle Health Force are examples of how communities of solution could operate on a national scale.

A community approach to COVID-19 provides an opportunity to address other crucial health care needs as well. Contact tracing, for example, demands an immediate robust workforce that can include trained public health workers, primary care clinicians and staff, medical and nursing students, and community health workers. Because no single health sector has the mission or capacity for comprehensive pandemic recovery, co-training these individuals would be a tangible shared effort. Adding training in basic preventive medicine, behavioral health screening, and referral training would broaden this work, allowing contact tracers to identify preventive health needs and help prevent and treat behavioral health challenges exacerbated by COVID-19. This will also create the long-lasting workforce necessary for future efforts Partnerships with medical, nursing, and other health professions' training institutions are essential to such efforts. Public health and primary care must also pool their expertise to assure equitable access to and delivery of these services, particularly as we prepare for mass serologic testing and immunization.

\section{An Enduring System of Community Care}

The multidisciplinary approach in "Health is a Community Affair," as well as initial communitybased approaches to mitigating COVID-19, are the foundations of an enduring system of communitybased care (Table 2). Working together, rather than competing as interest groups, can result in new ways of understanding and improving health - incorporating such factors as public education, law enforcement, social services, environment, and climate change. In the long-term, however, linking primary care, public health, oral health, behavioral health, and community health into a unified team will require substantial policy and culture shifts. ${ }^{28-29}$ The historic divide and diverse funding streams applied to public health, primary care, community health worker programs, and behavioral health are critical issues that must be addressed. Funding streams from Health Resources and Services Administration, Centers for Disease Control and Prevention, and public and private insurance are crucial to the development of a community care approach. Long-term efforts also require rethinking how schools of medicine, public health, behavioral health, and other allied health programs can be structured to enable communities of solution. By considering creative methods to support population health efforts and a combined workforce, funders can help disciplines and fields move beyond their separate silos to build communities of solution and the infrastructure and conditions to improve health and foster equity so that everyone has an opportunity to reach their full health potential.

With over 290,000 workers in public health and over 225,000 physicians in primary care, all of whom face significant systemic challenges, ${ }^{30}$ creating unified teams will require sustained effort. ${ }^{31,32}$ For example, retirements in both workforces are leading to concerns about whether there are enough workers to meet the country's needs. ${ }^{33,34}$ Both sectors are transforming workflows to adapt to the value-based payment models created by the Affordable Care Act. ${ }^{35}$ Both are investing in training and programs to address rising mortality from chronic diseases, substance use, and suicides. ${ }^{36}$ And both are struggling to exploit data in electronic health records to improve health care and health. ${ }^{37,38}$

Despite these challenges, there is a foundation that a unified workforce can build on: shared language, knowledge base, and mission. In parallel, public health and primary care teams address similar concerns by engaging similar types of health professionals. ${ }^{39}$ While this overlap may contribute to friction, it can also facilitate communication and connection. With the release of the National Academy of Medicine report on integration and the expansion of value-based payment, bridges across these siloes are emerging. ${ }^{9}$ A move away from the dominant medical fee-for-service payment model may be a crucial step toward shared efforts and collaboration. ${ }^{40}$ In a survey of over 17,000 public health workers, half reported that integrating with primary care as part of their daily work. ${ }^{32}$ One model that allows public health workers to collaborate with their counterparts in primary care is the community health team. Consisting of community health workers, public health specialists, social workers, and behavioral therapists, these teams 
Table 2. Building the COVID-19 Response and Recovery Community Health Infrastructure

\begin{tabular}{|c|c|}
\hline Goals & Objectives \\
\hline Expand the workforce & $\begin{array}{l}\text { Recruit and train (100,000 to 200,000) a new Community Health Worker Corps comprised of } \\
\text { public health workers, primary care practice staff, and members of the community } \\
\text { Introduce community health workers and primary care-public health extension agents } 44,45,47,48 \text { to } \\
\text { public health settings and primary care practices } \\
\text { Train community health workers to provide community-engaged behavioral health screening, } \\
\text { detection, referral, and education } \\
\text { Where available, add public health competencies to community health teams (which consist of social } \\
\text { workers, behavioral therapists, and community health workers) } \\
\text { Create a national program for locally based interpretation consortia for individuals of limited } \\
\text { English proficiency }\end{array}$ \\
\hline Train the workforce & $\begin{array}{l}\text { Develop a core medical school curriculum in primary care-public health collaboration, including a } \\
\text { public health rotation } \\
\text { Support inter and trans-disciplinary training } \\
\text { "Public health for the local primary care clinician:" Primary care residents and primary care practice } \\
\text { staff (nurses, medical assistants, and clinicians) will be trained by local public health staff in } \\
\text { testing, contact tracing, and immunity testing. } \\
\text { "Primary care for the local public health professional:" Public health professionals and students will } \\
\text { be trained by local primary care clinicians in screening, referral, tracking of MEB health, and } \\
\text { other primary care essentials } \\
\text { "Public health and primary care for all clinicians:" Provide all health profession students with } \\
\text { interprofessional education/training in testing, tracking, tracing, MEB screening, and other } \\
\text { primary care essentials }\end{array}$ \\
\hline Enhance collaboration & $\begin{array}{l}\text { Create opportunities for data sharing between public health and primary care that maintain } \\
\text { confidentiality but also facilitate rapid identification, contact tracing, and intervention } \\
\text { Engage funding agencies and payers to consider how to provide financial support for public health } \\
\text { and primary care teams } \\
\text { Establish a responsible federal agency to inspire, help guide, and sustain communities of solution } \\
\text { Engage professional associations and licensing and certification boards to promote transdisciplinary } \\
\text { professionalism, scope of practice, quality, and accountability. } \\
\text { Create activities/events for public health and primary care to co-create, co-brand, co-lead, co- } \\
\text { operate in local communities. This must include funds to pay primary care clinicians and public } \\
\text { health professionals to participate (i.e., replace patient encounter revenue). } \\
\text { Develop and/or enhance robust connections with community-led task forces charged to address and } \\
\text { mitigate the health care disparities of minority populations }\end{array}$ \\
\hline Conduct ongoing evaluation & $\begin{array}{l}\text { Create and sustain an analytic workforce to assess progress and drive improvement. } \\
\text { Plan, implement, coordinate, and fund clinical research, epidemiological studies, and community- } \\
\text { based participatory research to evaluate community of solution functions and interventions } \\
\text { Conduct studies that assess the impact of engagement of those most proximal to the problem in co- } \\
\text { creating solutions that foster equity } \\
\text { Conduct studies that assess the impact of models of care that bring together public health and } \\
\text { primary care } \\
\text { Evaluate the impact of new curricula on professional competencies and behavior } \\
\text { Develop research training programs that support public health and primary care professionals to } \\
\text { develop skills that enable them to become independently funded researchers who prioritize team } \\
\text { and systems-based approaches to change }\end{array}$ \\
\hline
\end{tabular}

Abbreviation: MEB, mental/emotional/behavioral.

coordinate with primary care practices, provide enhanced services, and connect patients with community organizations and public health departments. ${ }^{41,42}$ In Vermont, private payers partnered with Medicaid to pay for these teams, and ultimately, this investment generated savings. ${ }^{43}$ This blueprint highlights the feasibility of creating unified teams and the impact of scaling them to address current and future crises.

In the face of COVID-19, we have an opportunity to begin the slow dance of working together ${ }^{44}$ to build a structure and workforce that meet the needs of individuals and their communities. It is a task that no organization or discipline can accomplish alone, and it requires a long-term commitment. It is an opportunity to bring public health and primary care together in a unified effort to protect people from COVID-19, ${ }^{45}$ prevent, identify, and treat behavioral health issues exacerbated by unemployment and isolation; increase preventive services; manage acute and chronic conditions, and tackle upstream drivers of health inequities. We can begin immediately to work together to address the acute COVID-19 pandemic, allowing time for the 
necessary policy changes related to revenue, capital, and financing. ${ }^{46}$ Through ongoing efforts initiated today, we begin to build the trust and trustworthiness so crucial for this community of solution effort. Because health is a complex condition, not all health outcomes will pass through the combined efforts of a local community of solution. Many social drivers of health such as unemployment, inequitable educational opportunities, and racism must also be addressed through additional local, state, and federal efforts.

We can ensure that the massive COVID-19 response and recovery efforts result in a new way of addressing population health by joining the best of public health with the best of primary care. By building robust local communities of solution, both during and after the pandemic, we can truly improve and maintain the health and well-being of our communities-together.

To see this article online, please go to: http://jabfm.org/content/ 34/Supplement/S203.full.

\section{References}

1. Williams DR, Lawrence JA, Davis BA. Racism and health: evidence and needed research. Annu Rev Public Health 2019; 40:105-25.

2. Hardeman RR, Medina EM, Kozhimannil KB. Structural racism and supporting black lives - the role of health professionals. N Engl J Med 2016;375: 2113-5.

3. Powell JA. Structural racism: Building upon the insights of John Calmore. NCL Rev 2007;86.

4. Wang Z, Tang K. Combating COVID-19: health equity matters. Nat Med 2020;26:458

5. Souch JM, Cossman JS. A commentary on ruralurban disparities in COVID-19 testing rates per 100,000 and risk factors. J Rural Health 2020.

6. Laurencin CT, McClinton A. The COVID-19 pandemic: a call to action to identify and address racial and ethnic disparities. J Racial Ethn Health Disparities 2020.

7. Khunti K, Singh AK, Pareek M, Hanif W. Is ethnicity linked to incidence or outcomes of covid-19? BMJ 2020;369:m1548.

8. Chung RY-N, Dong D, Li MM. Socioeconomic gradient in health and the covid-19 outbreak. BMJ 2020;369:m1329.

9. Institute of Medicine. Primary Care and Public Health: Exploring Integration to Improve Population Health. Washington, DC: National Academies Press; 2012.

10. Sweeney SA, Bazemore A, Phillips RL, Etz RS, Stange KC. A reemerging political space for linking person and community through primary health care. Am J Public Health 2012;102 Suppl 3:S336-341.

11. Julia C, Saynac Y, Le Joubioux C, Cailhol J, Lombrail P, Bouchaud O. Organising community primary care in the age of COVID-19: challenges in disadvantaged areas. Lancet Public Health 2020.

12. Thomas P, Meads G, Moustafa A, Nazareth I, Stange KC, Donnelly Hess G. Combined horizontal and vertical integration of care: a goal of practice-based commissioning. Qual Prim Care 2008;16:425-32.

13. De Maeseneer J, van Weel C, Egilman D, Mfenyana K, Kaufman A, Sewankambo N. Strengthening primary care: addressing the disparity between vertical and horizontal investment. Br J Gen Pract 2008;58: 3-4.

14. Weiner SJ, VanGeest J, Abrams RI, Moswin A, Warnecke R. Managing the unmanaged: a case study of intra-institutional determinants of uncompensated care at healthcare institutions with differing ownership models. Med Care 2008;46:821-8.

15. Leider JP, Resnick B, Bishai D, Scutchfield FD. How much do we spend? Creating historical estimates of public health expenditures in the United States at the federal, state, and local levels. Annu Rev Public Health 2018;39:471-87.

16. Institute of Medicine. Medicine Financing Population Health Improvement: Workshop Summary. Washington, DC: The National Academies Press; 2015 .

17. Institute of Medicine. For the Public's Health: Investing in a Healthier Future. Washington, DC: The National Academies Press; 2012.

18. Wizemann T. (Rapporteur), Roundtable on Population Health Improvement, Board on Population Health and Public Health Practice, Institute of Medicine. Collaboration Between Health Care and Public Health: Workshop Summary (2015). Paper presented at: Opportunities at the Interface of Health Care and Public Health: A Workshop; Feb 5, 2015, 2015 (in press); National Academy of Sciences, Washington, DC.

19. NCCHS. Health is a Community Affair-Report of the National Commission on Community Health Services (NCCHS). Cambridge, MA: Harvard University Press; 1967.

20. American Board of Family Medicine Young Leaders Advisory Group. Communities of solution: the Folsom Report revisited. Ann Fam Med 2012;10:250-60.

21. Westfall JM. Cold-spotting: linking primary care and public health to create communities of solution. J Am Board Fam Med 2013;26:239-40.

22. Griswold KS, Lesko SE, Westfall JM, Folsom Group. Communities of solution: partnerships for population health. J Am Board Fam Med 2013;26:232-8.

23. Thompson D, Alper J. Exploring Equity in Multisector Community Health Partnerships: 
Proceedings of a Workshop. Washington, DC: The National Academies Press; 2018.

24. PHAB Staff and Writing Committee:, Aungst H, Ruhe M, Stange KC, et al. Boundary spanning and health: invitation to a learning community. London J Prim Care (Abingdon) 2012;4:109-15.

25. Ernst C, Chrobot-Mason D. Boundary Spanning Leadership. New York: McGraw-Hill; 2011.

26. Stange KC. Refocusing knowledge generation, application and education: Raising our gaze to promote health across boundaries. Am J Prev Med 2011;41: S164-S169.

27. Fink S. As Corona Virus Slams Houston Hospitals, It's Like New York All Over Again The New York Times. July 4, 2020.

28. Cohen DJ, Davis M, Balasubramanian BA, et al. Integrating behavioral health and primary care: consulting, coordinating and collaborating among professionals. J Am Board Fam Med 2015;28: S21-31.

29. Cohen DJ, Balasubramanian BA, Davis M, et al. Understanding care integration from the ground up: five organizing constructs that shape integrated practices. J Am Board Fam Med 2015;28: S7-S20.

30. The Larry A. Green Center. Quick COVID-19 Primary Care Patient Survey. https://www.greencenter.org/covid-patient-survey/. Published 2020. Accessed October 14, 2020.

31. Petterson SM, Liaw WR, Tran C, Bazemore AW. Estimating the residency expansion required to avoid projected primary care physician shortages by 2035. Ann Fam Med 2015;13:107-14.

32. Beck AJ, Boulton ML, Coronado F. Enumeration of the governmental public health workforce, 2014. Am J Prev Med 2014;47:S306-313.

33. Sellers K, Leider JP, Gould E, et al. The State of the US Governmental Public Health Workforce, 2014-2017. Am J Public Health 2019;109:674-80.

34. Draper DA, Hurley RE, Lauer JR. Public health workforce shortages imperil nation's health. Res Brief 2008;1-8.

35. Centers for Medicare \& Medicaid Services. Medicare Access and CHIP Reauthorization Act: Merit-Based Incentive Payment System \& Alternative Payment Models. In:2016: https://www.cms.gov/Medicare/ Quality-Initiatives-Patient-Assessment-Instruments/ Value-Based-Programs/MACRA-MIPS-and-APMs/ MACRA-MIPS-and-APMs.html. Accessed July 12, 2016.

36. Case A, Deaton A. Rising morbidity and mortality in midlife among white non-Hispanic Americans in the 21st century. Proc Natl Acad Sci USA 2015;112: 15078-83.

37. Young RA, Burge SK, Kumar KA, Wilson JM, Ortiz DF. A Time-Motion Study of Primary Care Physicians' Work in the Electronic Health Record Era. Fam Med 2018;50:91-9.

38. Shanafelt TD, Hasan O, Dyrbye LN, et al. Changes in Burnout and Satisfaction With WorkLife Balance in Physicians and the General US Working Population Between 2011 and 2014. Mayo Clin Proc 2015;90:1600-13.

39. Beck AJ, Coronado F, Boulton ML, Merrill JA, Group PHEW, Public Health Enumeration Working Group. The Public Health Workforce Taxonomy: Revisions and Recommendations for Implementa-tion. J Public Health Manag Pract 2018;24:E1-E11.

40. Basu S, Phillips RS, Phillips R, Peterson LE, Landon BE. Primary Care Practice Finances in the United States Amid the COVID-19 Pandemic. Health Aff (Millwood) 2020;39:1605-14.

41. Bielaszka-DuVernay C. Vermont's Blueprint for medical homes, community health teams, and better health at lower cost. Health Aff (Millwood) 2011;30:383-6.

42. Centre for Health Care Strategies \& State Health Access Data Assistance CenterCenterCommunity Care Teams: An Overview of State Approaches. In:2016: https://www.chcs.org/media/Community-Care-TeamsAn-Overview-of-State-Approaches-030316.pdf.

43. Jones C, Finison K, McGraves-Lloyd K, et al. Vermont's Community-Oriented All-Payer Medical Home Model Reduces Expenditures and Utilization While Delivering High-Quality Care. Popul Health Manag 2016;19:196-205.

44. Weiner BJ, Lewis MA, Clauser SB, Stitzenberg KB. In search of synergy: strategies for combining interventions at multiple levels. J Natl Cancer Inst Monogr 2012;2012:34-41.

45. Westfall JM, Petterson S, Rhee K, et al. A New "PPE" For A Thriving Community: Public Health, Primary Care, Health Equity. Health Affairs Blog 2020;. September 25.

46. Krist AH, DeVoe JE, Cheng A, Ehrlich T, Jones SM. Redesigning Primary Care to Address the COVID-19 Pandemic in the midst of the Pandemic. Ann Fam Med July 2020;18:349-54.

47. Grumbach K, Mold JW. A health care cooperative extension service: transforming primary care and community health. JAMA 2009;301:2589-91.

48. Health Extension Toolkit. http://healthextension toolkit.org/. Accessed July 7, 2020. 